\title{
Flipping Software Engineering Course to Improve Students' Practical Skills
}

\author{
Teduh Dirgahayu \\ Universitas Islam Indonesia \\ Yogyakarta, Indonesia
}

\begin{abstract}
This paper presents the use of flipped learning in Software Engineering course. Before class, the teacher provides several online videos to facilitate students' as individual learning. Moreover, at the beginning of each class, students are given a short quiz to assess their learning ability. During class, students in teams work on a software development project under teacher supervision. After school, teams continue to finish the project unsupervised. Later teams must present their software specifications. The teacher gives feedback for students to improve the specifications before grading. This learning approach gives a positive impact on students' practical skills. The students' learning ability however still need to be improved.
\end{abstract}

Keywords—flipping software; students; practical skills

\section{INTRODUCTION}

The conceptional issues show that sometimes the lecturer or a teacher did not put into the consideration of the environment or natural resources or the lively community hoods into the learning process. Moreover, [1] believes the attitudes and lecturer behaviour in the development of the model of learning and the media learning do not focus on the students. The focus of the learning media and learning process only centred on the lecturer and low students participation in the process of learning. Factor that may cause the low quality of learning process is the ability of the students to adapt and to transform their needs to the learning media. Therefore there is a need to improve this learning media or learning tools by using several models of learning. This model also can improve the student's knowledge by using several patterns of the syntax design of learning patterns. The learning models should be planning and implement directly to gain more students knowledge and information in the classrooms and outside the classrooms.

The undergraduate students of the degree program in Computer Science have to learn software engineering (SE) [2]. In SE, some software development process models have been established, e.g. linear, iterative, spiral, and prototyping [3]. Essentially those process models consist of four activities, i.e. requirements analysis, software design, software construction and software testing [4].

In Universitas Islam Indonesia (UII), SE course is aimed at developing students' basic competencies in software development. As requirements analysis and software design are critical for software success, $43 \%$ of total time in SE course is assigned for those analysis and design activities. It includes learning and practising requirements analysis and software design. Moreover, students in teams work on projects to produce software requirement specification (SRS) and software design description (SDD). To be able to produce those specifications, students must develop their practical skills in software modelling, including the use of modelling tools.

From five years experience in teaching SE course, the lecturer has learned that time available for students to work under lecturer supervision was very limited. Sadly, this situation leads to low-quality specifications.

Therefore, the teacher uses flipped learning to give more time for students doing their work under supervision. The teacher expects that students' practical skills will improve.

The objectives of this paper are to present (i) how flipped learning is used in SE course and (ii) its impact on students' practical skills. This article is further structured as follows. Section 2 presents literature review related to flipped learning. Section 3 describes how flipped learning is used in the course. Section 4 presents the impact of the learning approach on students' practical skills. Finally, section 5 concludes this paper.

\section{LITERATURE REVIEW}

Flipping learning is traditional teaching with the reversed model. Giving the material to the students is done outside the classroom through the audio visual method or reading, and after that followed by learning in the classroom. Students are divided into groups to assimilating that knowledge about the previous material, such as problem solving, debate or discussion (FLN 2014). Table 1 illustrates the phases in flipped learning.

TABLE I. TABLE STYLES

\begin{tabular}{|c|c|c|}
\hline Phase & Activity & Location \\
\hline 1 & Teacher delivers content & Off class \\
\hline 2 & Students assimilate the content & Off class \\
\hline 3 & $\begin{array}{l}\text { Students do activity to support the } \\
\text { assimilation }\end{array}$ & $\begin{array}{l}\text { In class, } \\
\text { supervised }\end{array}$ \\
\hline 4 & $\begin{array}{l}\text { Students do assignment to consolidate the } \\
\text { assimilation }\end{array}$ & $\begin{array}{l}\text { In class, } \\
\text { supervised }\end{array}$ \\
\hline
\end{tabular}

Group learning used In-class time (phase 3) [5]. Individual learning before in-class time (phase 2) is hence fundamental. 
Contents are usually provided in videos (phase 1) so students can have their control over time, place and learning pace [6].

Students are more engaged to the course contents to drive the students participating actively in group learning [7]. Active participation indicates that students have a thorough understanding of the contents [5]. In its early years, flipped learning was applied in elementary education only. Nowadays, it has been implemented in university and other higher education [8], e.g. health [7], economics [9] and social [10].

\section{METHOD}

The teacher creates videos for content delivery (Phase 1) using Google Hangouts On Air and uploads the videos on YouTube. Each video contains a single topic with minimum references to other videos. Several videos for the same week are put on a playlist to allow students to learn the course contents systematically.

These videos are to facilitate students in individual learning (Phase 2). As each video contains a single topic only, the videos ease students to replay only topics that they do not understand yet. To assess students' understanding, the teacher conducts a short quiz at the beginning of each in-class time. The step is also to determine whether students can do individual learning using videos.

During the in-class time (phase 3), students in teams work on their SRSs and SDDs under teacher supervision as in [10]. As the projects cannot be completed within the time available in the class, students must continue to finish their SRSs and SDDs unsupervised off class. In the end, teams present their SRSs and SDDs to get feedback from the teacher. Teams are allowed to improve the specifications before grading (phase 4).

\section{RESUlt AND DisCUSSION}

\section{A. Video duration}

At the beginning of the semester, the teacher conducts a questionnaire to know students' preference on video duration. The result is shown in Figure 1. Most students (47\%) prefer to watch 5-10 minutes videos to minimise boredom [7]. This very short duration brings a challenge in delivering a clear and concise presentation of a topic.

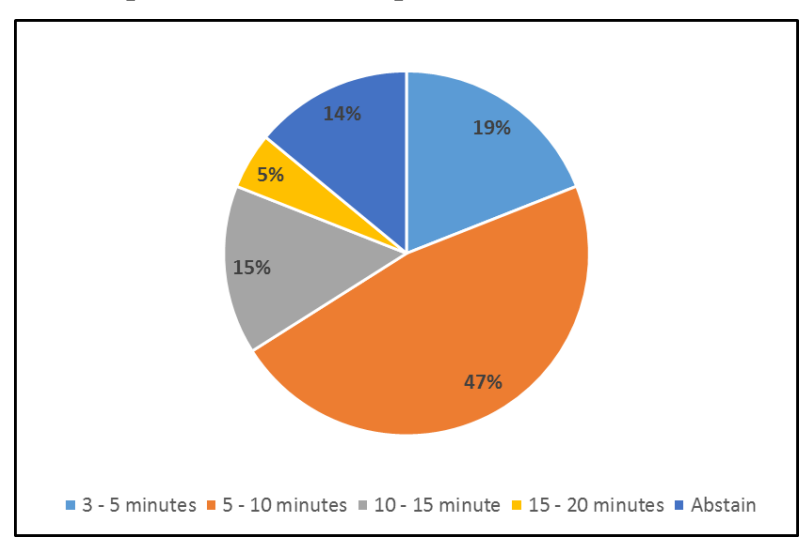

Fig. 1. Students' preference on video duration

\section{B. Students' learning ability}

Every week short quizzes are given at the beginning of inclass time. The first quiz measures the student ability about concepts of requirements analysis. The second quiz aims to find the student knowledge about software requirements modelling. Furthermore, the knowledge about software behaviour design is the topic of evaluation. The last quiz has topic about software architecture design. Figure 2 depicted the results (on scale 10). Unfortunately, the average results of all quizzes are less than 6.00 .

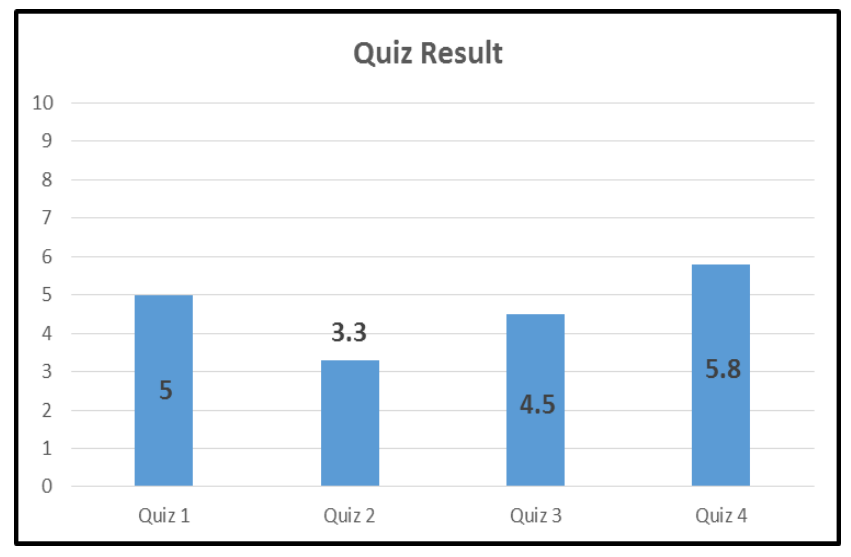

Fig. 2. Quiz results

Two possible explanations about the quiz result. Firstly, students' learning ability is poor. This could be because individual learning using videos is new for them. Secondly, the questions are beyond student's expectation. There is an improvement from Quiz 2 to 4 as they could to expect questions that will be given.

\section{Impact on students' practical skills}

Impact on students' practical skills is indicated from the grades of their SRSs and SDD. The grades are divided into three categories, i.e. poor (grade $<6.0)$, fair $(6 \leq$ grade $<8.0)$, and good (grade $\geq 8.0$ ). Figure 3 and 4 show that flipped learning let most students get good grades (74\% for SRS and $72 \%$ for SDD). Students that get poor grades are only a few (10\% for SRS and 0\% for SDD). Therefore, flipped learning gives a positive impact on students' practical skills.

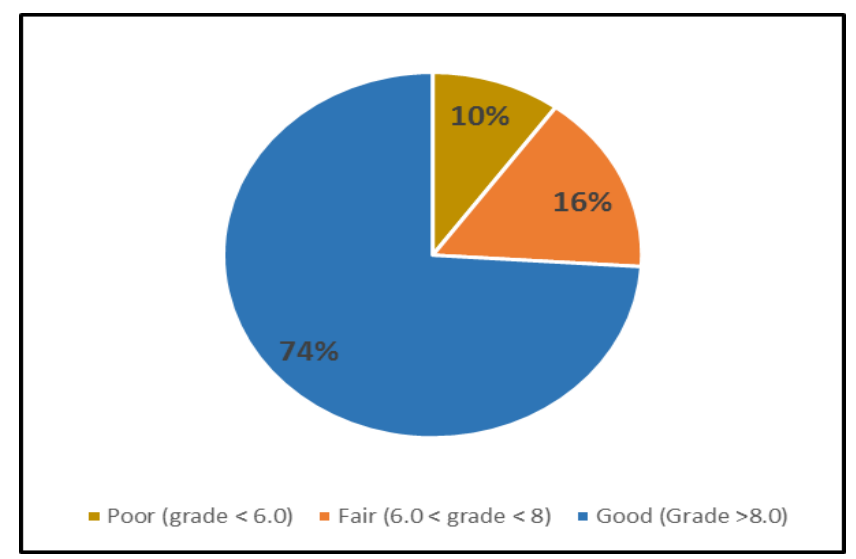

Fig. 3. Grades of SRS 
TABLE III. COVERAGE AND DEPTH OF WEEKLY VIDEOS

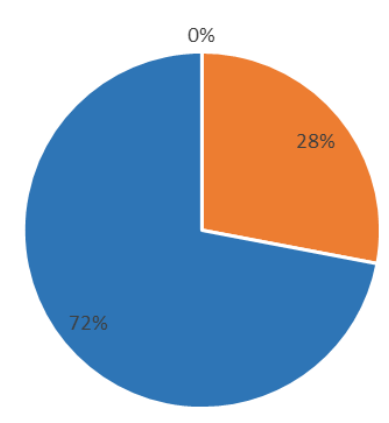

- Poor (grade <6.0) I- Fair $(6.0<$ grade < 8$) \quad$ " Good (Grade > 8.0)

Fig. 4. Grades of SDD

There are two explanations about the impact of practical skills.Firstly, the students have sufficient time to work on their project under teacher supervision. Secondly, students get feedbacks from the teacher when presenting their specifications and sufficient time to elaborate the feedbacks before grading.

\section{Peer review on videos}

The teacher asks other teachers of SE course to consider the videos. The review focused on content coverage and depth and the cleanliness of content presentation

The review is done using questionnaire with Likert scale: strongly disagree $=1$; Disagree $=2$; neither agree or disagree $=3$; Agree $=4$; and strongly agree $=5$.

The review results in content coverage and depth in Table 2. The average score is 2.3 (tends to disagree), which means that the coverage and depth of the content are sufficient.

\section{TABLE II. COVERAGE AND DEPTH OF WEEKLY VIDEOS}

\begin{tabular}{|l|l|}
\hline \multicolumn{1}{|c|}{ Statement } & Score \\
\hline The coverage needs to be narrowed & 2.5 \\
The coverage needs to be expanded & 2.0 \\
The depth needs to be swallowed & 1.8 \\
The depth needs to be deepened & 3.0 \\
Average & 2.3 \\
\hline
\end{tabular}

The review results on the cleanliness of content presented in Table 3. The average score is 4.5 (between agree and strongly agree), which means that the video contents are presented clearly.

\begin{tabular}{|l|l|}
\hline \multicolumn{1}{|c|}{ Statement } & Score \\
\hline The duration of 5-10 minutes per video is sufficient & 4.8 \\
Narration for presenting the contents is clear & 4.3 \\
Texts in slide are sufficient to explain the contents & 4.5 \\
Figures correctly illustrate the contents & 4.5 \\
Average & 4.5 \\
\hline
\end{tabular}

\section{CONCLUSION}

This paper has presented the use of flipped learning in SE course. This learning approach gives a positive impact on students' practical skills. The students' learning ability however still need to be improved. Factors of this ability will be further investigated.

\section{ACKNOWLEDGMENT}

The author thanks to the Board of Academic Development UII for funding this research. The author also thanks the teachers of SE course in UII for participating in this research.

\section{REFERENCES}

[1] A. Suprijono, "Cooperative Learning took VII." Yogyakarta: Pustaka Pelajar, 2012.

[2] A. C. M. J. T. Force, “Computer science curricula 2013: Curriculum guidelines for undergraduate degree programs in computer science," Technical report, Association for Computing Machinery (ACM) IEEE Computer Society, 2013.

[3] Sommerville I, Software Engineering, 9th ed. Wesley: Pearson Addison, 2010.

[4] C. S. IEEE, P. Bourque, and R. E. Fairley, Guide to the Software Engineering Body of Knowledge (SWEBOK(R)): Version 3.0, 3rd ed. Los Alamitos, CA, USA: IEEE Computer Society Press, 2014.

[5] J. Bergmann and A. Sams, Flipped learning: Gateway to student engagement. International Society for Technology in Education, 2014.

[6] C. Steeples, P. Goodyear, and H. Mellar, "Flexible learning in higher education: the use of computer-mediated communications," Comput. Educ., vol. 22, no. 1-2, pp. 83-90, 1994.

[7] M. B. Gilboy, S. Heinerichs, and G. Pazzaglia, "Enhancing student engagement using the flipped classroom," J. Nutr. Educ. Behav., vol. 47, no. 1, pp. 109-114, 2015.

[8] J. O'Flaherty and C. Phillips, "The use of flipped classrooms in higher education: A scoping review," Internet High. Educ., vol. 25, pp. 85-95, 2015.

[9] T. Roach, "Student perceptions toward flipped learning: New methods to increase interaction and active learning in economics," Int. Rev. Econ. Educ., vol. 17, pp. 74-84, 2014.

[10] T. Wanner and E. Palmer, "Personalising learning: Exploring student and teacher perceptions about flexible learning and assessment in a flipped university course," Comput. Educ., vol. 88, pp. 354-369, 2015. 